\title{
29. ORGANIC GEOCHEMISTRY OF SOME CRETACEOUS BLACK SHALES FROM SITES 367 AND 368; LEG 41, EASTERN NORTH ATLANTIC
}

\author{
G. Deroo, J.P. Herbin, J. Roucache, and B. Tissot, \\ Institut Francais du Petrole, 1 et 4 avenue de Bois Preau, 92502 Rueil-Malmaison, France \\ and \\ P. Albrecht, J. Schaeffle, Institut de Chimie, Strasbourg, France
}

\begin{abstract}
The black shale encountered in Cretaceous cores of the Cape Verde area during the DSDP Leg 41 are of marine origin and correspond to excellent potential oil source rocks. They have a low content of humic compounds.

Pyrolysis assays, chloroformic extracts, and kerogen data attest to a relatively low stage of evolution for samples at Site 367 (Cape Verde Basin). The samples from Site 368 (Cape Verde Rise) are more evolved, and the deeper ones would be located at the beginning of the principal zone of oil formation.
\end{abstract}

\section{INTRODUCTION}

The aim of this paper is to define, from a geochemical point of view, the black shale recovered in Cretaceous cores of the Cape Verde area, during DSDP Leg 41.

A pyrolysis assay for the detection of hydrocarbons was run on raw samples and chloroformic extractions were performed. These are useful to characterize the type of organic matter in sediments. Also, a study was made of the insoluble fraction including the humic compounds and the kerogen fraction. The elemental composition of kerogen and the proportion of humic compounds in organic matter yield valuable indications about the marine autochthonous versus continental organic material. Furthermore, humic compounds are more abundant in immature than in mature sediments, whereas the kerogen fraction is present in both immature and mature sediments.

\section{SAMPLING}

Seven samples of $50 \mathrm{~g}$ each were studied from Sites 367 and 368 (Figure 1). Five samples are black shale of Late Cretaceous to Albian age and two are shale of Late and Early Cretaceous age. Their stratigraphy and lithological description are given in Figure 2. The two analyzed samples from Site 368 are from either side of a basalt sill.

\section{ANALYTICAL METHODS}

The samples were first freeze-dried. Then they were ground in an AUREC pulverizer (size grain $\cong 90 \mu \mathrm{m}$ ). The succession of analytical processes is shown on Figure 3. Organic carbon was analyzed with a LECO apparatus. A pyrolysis assay was made on raw samples for rapid source rock and maturation characterization. The method is deduced from kerogen experimental studies (Durand and Espitalie, 1973; Espitalie et al., 1973; Tissot et al., 1974). Equivalent parts of the

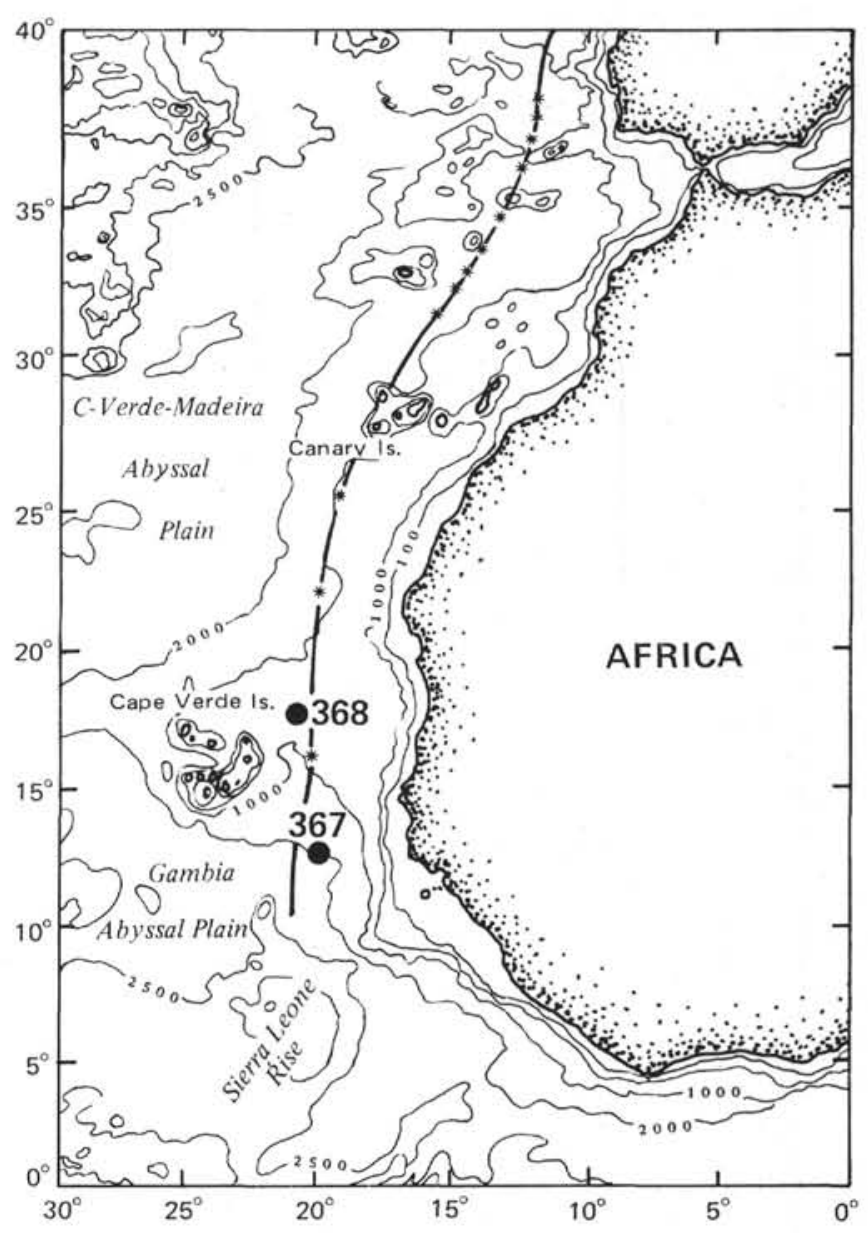

Figure 1. Location of DSDP Sites 367 and 368.

ground samples were then extracted with chloroform and the extracts fractionated according to a method described in Huc et al. (1976). The total humic compounds were extracted from the insoluble part of 




Figure 2. Stratigraphic location of samples.

rock and humic acids were separated from fulvic acids (Huc, 1973). The new insoluble part corresponds to humic and the nonhydrolysable fraction to kerogen (Durand et al., 1972; Robin et al., 1976). Analysis of organic content from total humic compounds and from the fulvic fraction was performed with a Carmograph Wosthoff apparatus. Elemental analyses of $\mathrm{C}, \mathrm{H}, \mathrm{O}, \mathrm{N}$, $\mathrm{S}$, and $\mathrm{Fe}$ plus ash content were measured on kerogen and calculations were made on a mineral-free basis.

\section{DETAILED RESULTS}

\section{Carbonate Carbon (Table 1)}

All samples show a low content of carbonates (1\% to $23 \%$ ) and the richest was an Albian black shale from Section 367-22-6.

\section{Organic Carbon (Table 1)}

The organic carbon content varied from $36 \%$ to $6 \%$ for the black shales, $4 \%$ for the Lower Cretaceous shale of Site 367, and 3\% for the Upper Cretaceous sandy shale of Site 368.

\section{Pyrolysis Assay and Organic Matter Characterization (Table 2, Figure 4)}

The pyrolysis assay method (Espitalié et al., in press) gives a rough estimate of the elemental analysis method on kerogen (Tissot et al., 1974). The combined oxygen and hydrogen indexes related to organic carbon are used for pyrolysis assays. $\mathrm{H} / \mathrm{C}$ and $\mathrm{O} / \mathrm{C}$ atomic ratios were used for kerogen. They allow three types of organic matter to be defined; types 1, 2, and 3 (Figure 4). The hydrogen index is expressed in milligrams of hydrocarbon compounds, related to a gram of organic carbon, and the oxygen index in milligrams of carbon dioxide, related to a gram of organic carbon. The temperature of the maximum hydrocarbon production during pyrolysis assays corresponds to the immature zone for the $400^{\circ}-400^{\circ} \mathrm{C}$ range, to the main oil zone or mature zone from $440^{\circ}-460^{\circ} \mathrm{C}$, and up to $460^{\circ} \mathrm{C}$ to gas issued from cracking, i.e., the metamorphosed zone.

The maximum of hydrocarbon production during pyrolysis was reached within a low range of temperatures, between $396^{\circ}$ and $436^{\circ} \mathrm{C}$. Even for the oldest samples from Sites 367 and 368, the temperatures did not reach the main zone of oil formation.

The six black shale samples (Table 1) belong to high potential source rocks of petroleum (Table 2); the three Upper Cretaceous samples (367-18-2, and 368-63-3) are close to type 1 and the two others of Cenomanian and Albian ages (367-20-3 and 367-22-6) are close to type 2. They can be compared to immature material of type 1 where the hydrogen index value is around 600 or more and to type 2 with values of $450-500$ (Table 2). Oxygen indexes for the two types are lower than 50 .

Sections 368-59-1 and 367-23-2 have intermediate values between reference types 2 and 3. However, Section 368-59-1 is close to the type 2 and Section 36723-2 is similar to type 3 .

Type 3 kerogens correspond mainly to higher plant detritus and humic continental matter. Their potential for oil is usually lower than for types 1 and 2 even if their gas yield is of the same importance. Type 2 kerogens are common in marine sediments with autochthonous organic matter and type 1 corresponds to algal material. Both of them are rich in saturated C$\mathrm{H}$ groups and their potential for oil is good to excellent.

Study of Chloroformic Extracts (Table 3, Figures 5, 6, 7, and 8 )

All the studied samples (Table 3 ) provided large contents of extract (100 to $1700 \mathrm{mg}$ ). Their fractionation was performed with the thin layer chromatography (TLC) method. The extract/organic carbon ratio of Site 367 samples was medium (0.04 to 0.09 ) with a large fraction (Figure 5) of NSO compounds (78\%-88\%). The extract/organic carbon ratio was higher $(0.11$ and 0.24$)$ for the two samples from Site 368 and the NSO compounds content was lower (63\% and $68 \%)$. The gas chromatography analysis of the saturated fraction for the two groups of extracts revealed a $\mathrm{C} 15$ to $\mathrm{C} 30$ normal alkanes distribution plus the related isoprenoids, commonly present in the saturated fraction of ancient sediments (Figure 6). The normal alkanes distribution is characterized by a high odd-toeven carbon number predominance between $\mathrm{C} 15$ and C29 for Site 367 samples with an increasing distribution from $\mathrm{C} 15$ to $\mathrm{C} 29$. The $n$-alkanes distribution from Site 368 samples is relatively flat except for the predominance of odd-to-even carbon number $n$-alkanes in the $\mathrm{C} 25-\mathrm{C} 29$ range. 


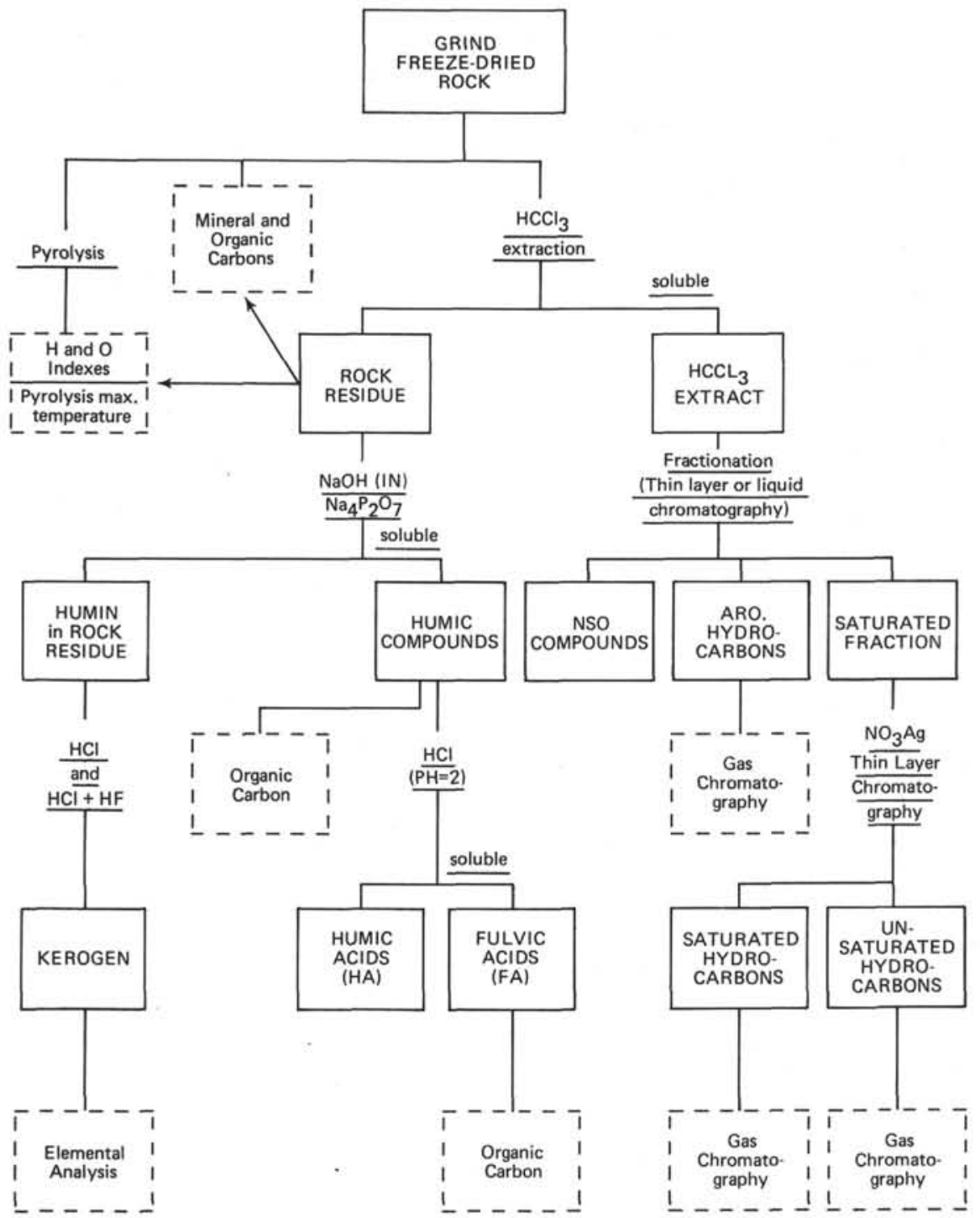

Figure 3. Schematic analytical processes.

TABLE 1

Location of Samples, Lithology and Age, and Carbon Data

\begin{tabular}{|c|c|c|c|c|c|c|}
\hline \multirow[b]{2}{*}{$\begin{array}{c}\text { Sample } \\
\text { (Interval in } \mathrm{cm} \text { ) }\end{array}$} & \multirow[b]{2}{*}{$\begin{array}{l}\text { Depth Below } \\
\text { Sea Floor } \\
\text { (m) }\end{array}$} & \multirow[b]{2}{*}{ Lithology } & \multirow[b]{2}{*}{ Age } & \multirow[b]{2}{*}{$\mathrm{CaCO}_{3}$} & \multicolumn{2}{|c|}{ Organic Carbon } \\
\hline & & & & & $\begin{array}{c}\mathrm{Before} \\
\mathrm{HCCl}_{3} \\
\text { Extraction }\end{array}$ & $\begin{array}{c}\mathrm{After} \\
\mathrm{HCCl}_{3} \\
\text { Extraction }\end{array}$ \\
\hline \multicolumn{7}{|l|}{ Site 367} \\
\hline $\begin{array}{l}18-2,80-85 \\
18-2,104-109 \\
20-3,38-48 \\
22-6,0-10 \\
23-2,0-10\end{array}$ & $\begin{array}{l}638.30 \\
638.54 \\
687.88 \\
728.00 \\
777.50\end{array}$ & $\begin{array}{l}\text { Black shale } \\
\text { Black shale } \\
\text { Black shale } \\
\text { Black shale } \\
\text { Interbedded } \\
\text { shale and clay }\end{array}$ & $\begin{array}{l}\text { Upper Cretaceous } \\
\text { Upper Cretaceous } \\
\text { Cenomanian } \\
\text { Albian } \\
\text { Lower Cretaceous }\end{array}$ & $\begin{array}{r}6 \\
1 \\
13 \\
23 \\
13\end{array}$ & $\begin{array}{r}36.09 \\
36.09 \\
9.93 \\
6.10 \\
4.08\end{array}$ & $\begin{array}{r}33.40 \\
33.40 \\
9.49 \\
5.83 \\
3.96\end{array}$ \\
\hline \multicolumn{7}{|l|}{ Site 368} \\
\hline $59-1,97-107$ & 939.47 & $\begin{array}{l}\text { Sandy black } \\
\text { shale }\end{array}$ & Upper Cretaceous & 4 & 3.30 & 3.00 \\
\hline $63-3,17-27$ & 978.17 & Black shale & Turonian-Albian & 10 & 7.60 & 6.12 \\
\hline
\end{tabular}

Phytane and pristane isoprenoids are also present in abundance and phytane is the most important (17.35\%$26.86 \%$ of total C14-C30 n-alkanes) isoprenoid (Figure
6). A large hump in the C29-C33 range of n-alkanes (Figures $7 \mathrm{a}, \mathrm{b}$ ) is present, except for the older section (368-63-3) (Figure 7c). It corresponds to unsaturated 
TABLE 2

Data of Pyrolysis Essays

\begin{tabular}{|c|c|c|c|c|c|}
\hline $\begin{array}{c}\text { Sample } \\
\text { (Interval in } \mathrm{cm} \text { ) }\end{array}$ & $\begin{array}{l}\text { Depth Below } \\
\text { Sea Floor } \\
\text { (m) }\end{array}$ & $\begin{array}{l}\text { Organic } \\
\text { Carbon } \\
\text { (wt \%) }\end{array}$ & $\begin{array}{l}\text { Hydrogen Index } \\
\text { (mg Hydroc. } \\
\text { Compounds/ } \\
\text { g. Org. Carb.) }\end{array}$ & $\begin{array}{l}\text { Oxygen Index } \\
\text { (mg CO } 2 / \\
\text { g. Org. Carb.) }\end{array}$ & $\begin{array}{c}\text { Pyrolysis } \\
\text { Temperature }\left({ }^{\circ} \mathrm{C}\right)\end{array}$ \\
\hline \multicolumn{6}{|l|}{ Site 367} \\
\hline $\begin{array}{l}18-1,80-85 \\
18-2,104-109 \\
20-3,38-48 \\
22-6,0-10 \\
23-2,0-10\end{array}$ & $\begin{array}{l}638.30 \\
638.54 \\
687.88 \\
728.00 \\
777.50\end{array}$ & $\begin{array}{r}30.86 \\
34.19 \\
9.71 \\
6.13 \\
4.15\end{array}$ & $\begin{array}{l}655 \\
604 \\
477 \\
453 \\
181\end{array}$ & $\begin{array}{l}23 \\
20 \\
44 \\
58 \\
86\end{array}$ & $\begin{array}{l}403 \\
396 \\
411 \\
419 \\
431\end{array}$ \\
\hline \multicolumn{6}{|l|}{ Site 368} \\
\hline $\begin{array}{l}59-1,97-107 \\
63-3,17-27\end{array}$ & $\begin{array}{l}939.47 \\
978.17\end{array}$ & $\begin{array}{l}3.14 \\
6.92\end{array}$ & $\begin{array}{l}313 \\
496\end{array}$ & $\begin{array}{l}24 \\
12\end{array}$ & $\begin{array}{l}423 \\
436\end{array}$ \\
\hline
\end{tabular}

TABLE 3

Chloroformic Extracts

\begin{tabular}{|c|c|c|c|c|c|c|c|}
\hline \multirow{3}{*}{$\begin{array}{c}\text { Sample } \\
\text { (Interval in } \mathrm{cm} \text { ) }\end{array}$} & \multirow{3}{*}{$\begin{array}{l}\text { Depth Below } \\
\text { Sea Floor } \\
\text { (m) }\end{array}$} & \multirow{3}{*}{$\begin{array}{l}\mathrm{HCCl}_{3} \\
\text { Extract } \\
\text { (wt mg) }\end{array}$} & \multirow{3}{*}{$\begin{array}{l}\text { Extract } \\
\text { Rock } \\
\text { (wt \%) }\end{array}$} & \multirow{3}{*}{$\begin{array}{l}\text { Extract } \\
\text { Org. Carb. } \\
\text { (wt) }\end{array}$} & \multicolumn{3}{|c|}{$\begin{array}{c}\text { Thin-Layer } \\
\text { Chromatography }\end{array}$} \\
\hline & & & & & $\begin{array}{c}\text { NSO } \\
\text { Compounds }\end{array}$ & $\begin{array}{r}\text { Hydr } \\
\text { Frac }\end{array}$ & $\begin{array}{l}\text { carb. } \\
\text { lons }\end{array}$ \\
\hline & & & & & (\%) & Aro. (\%) & Sat. (\%) \\
\hline \multicolumn{8}{|l|}{ Site 367} \\
\hline $18-2,80-109$ & 638.30 & 1680.9 & 3.36 & 0.093 & 88 & 7 & 5 \\
\hline $20-3,38-48$ & 687.88 & 290.3 & 0.54 & 0.055 & 78 & 12 & 10 \\
\hline $22-6,0-10$ & 728.00 & 265.4 & 0.33 & 0.043 & 81 & 11 & 8 \\
\hline $23-2,0-10$ & 777.50 & 101.7 & 0.15 & 0.037 & 88 & 7 & 5 \\
\hline \multicolumn{8}{|l|}{ Site 368} \\
\hline $59-1,97-107$ & 939.47 & 244.8 & 0.37 & 0.114 & 68 & 18 & 14 \\
\hline $63-8,17-27$ & 978.17 & 1424.3 & 1.85 & 0.243 & 63 & 18 & 19 \\
\hline
\end{tabular}

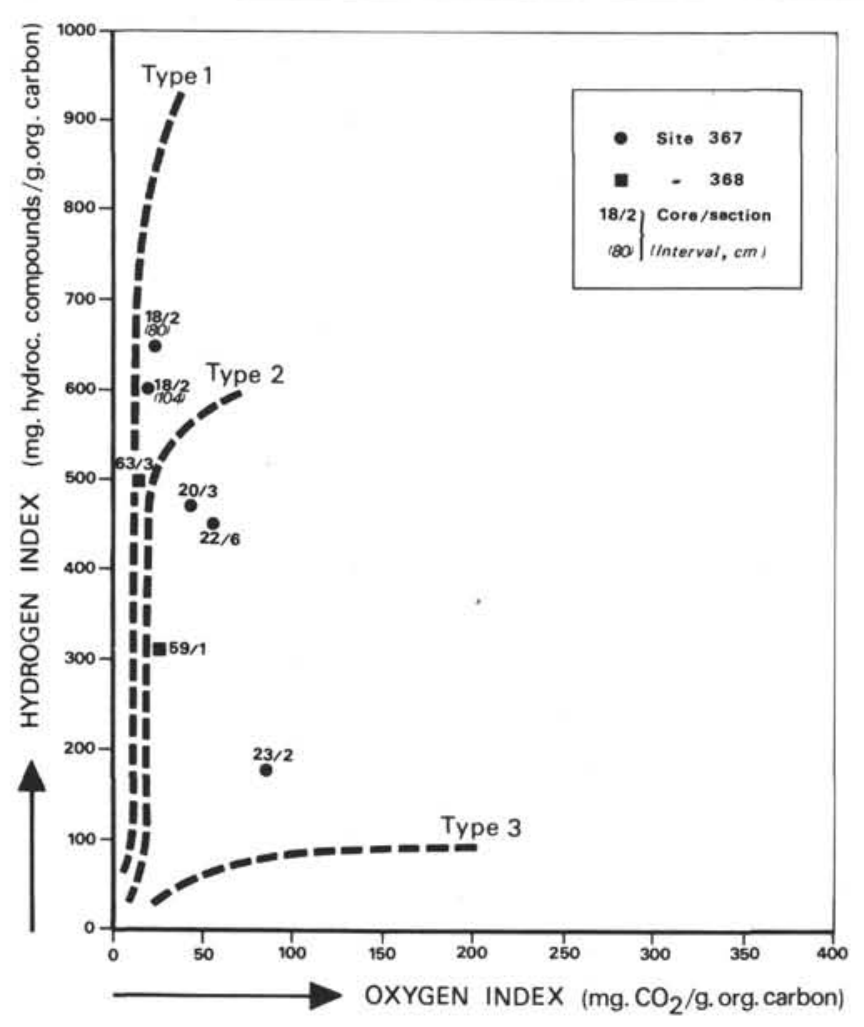

Figure 4. Pyrolysis essays. Hydrogen and oxygen index (data related to organic carbon). compounds probably of polycyclic structures as by gas chromatography of the unsaturated fraction (Figures $7 \mathrm{a}, \mathrm{c}$, bottom).

The unsaturated compounds were obtained from TLC fractionation upon layers coated with $\mathrm{AgNO}_{3}$.

The odd predominance shown by n-alkanes, a large content of isoprenoids (compared to n-alkanes), and the occurrence of unsaturated cyclic hydrocarbons are indicative of an early stage of evolution sometime before the beginning of oil genesis and expulsion. A somewhat higher evolution is shown by the samples of Site 368, especially for the oldest sample (Section 36863-31). This sample shows a more flattened or slightly decreasing distribution of the C14-C 30 n-alkanes and a much lower content of unsaturated hydrocarbons (Figure 7), compared to a larger content of extract and hydrocarbons in the samples from Site 367. The important contribution of supposed polycyclics in the total saturated fraction is characteristic of the marine type of organic matter usually found associated with immature samples of the type 2 kerogen. The polycyclics correspond to possible precursors of sterane and triterpane groups of compounds.

The chromatograms obtained with the flame ionization detector (FID) were generally low, especially in the $\mathrm{C}_{30}+$ range because the yield of aromatic fraction was poor for all the samples. However, a C15-C20 mode was detected. That mode, located at the beginning of the chromatogram, corresponds to mono- and 

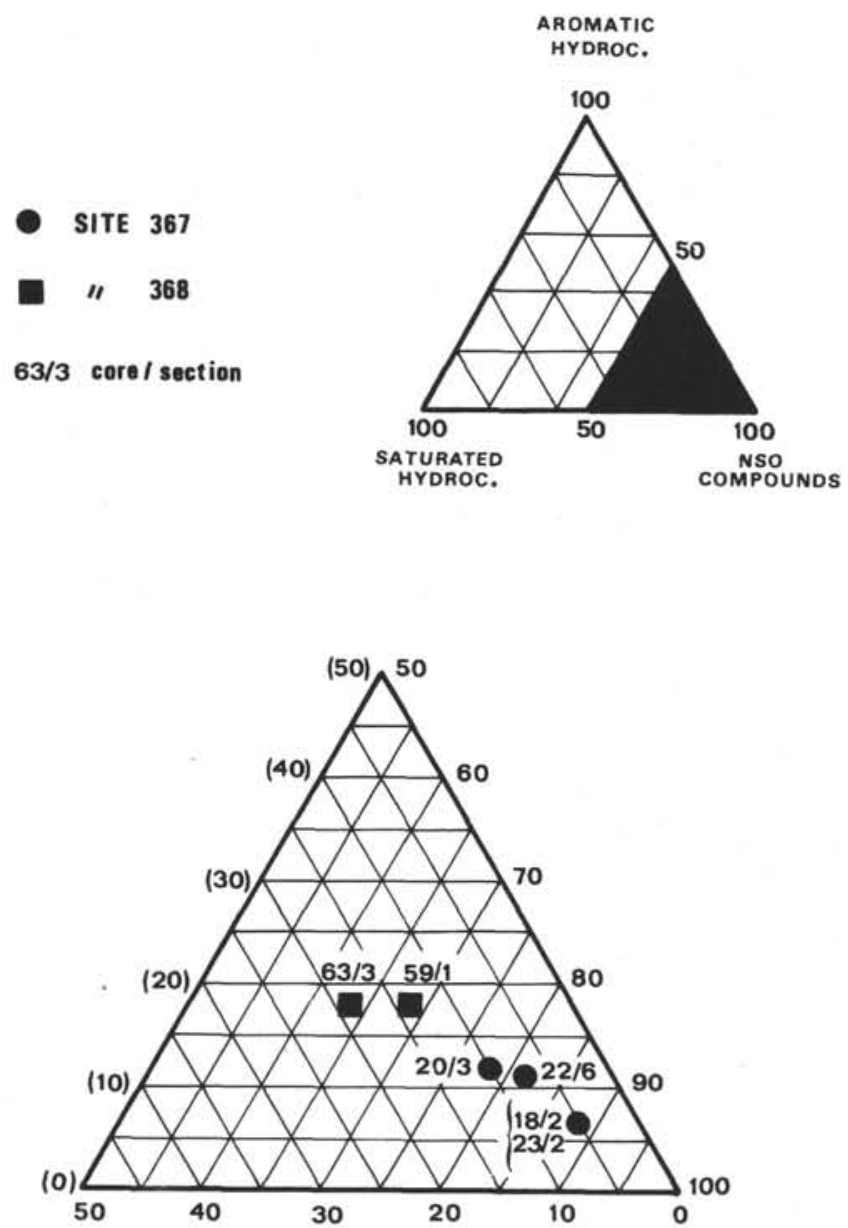

Figure 5. Gross composition of the chloroformic extracts.

diaromatic molecules with a probable monoaromatic predominance. The chromatogram from the flame photometric detector (FPD) show in the older samples, such as 368-63-3 (Figure 8), benzothiophenes in the C15-C20 range (Castex et al., 1974).

\section{Study of Humic Compounds (Table 4)}

Five samples were analyzed for humic compounds (Table 4). The contents of humic material in cores from Site 367 are generally low compared with their low stage of evolution ( $<14 \%$ of total organic carbon). The lowest content is for the black shale with the highest organic carbon content, Core 18 , Section 2 . Such a low proportion of humic material is related to a relatively low stage of the catagenesis and is indicative of a marine origin for the organic matter.

The only black shale sample from Site 368 (Core 63, Section 3) yielded a very poor content of humic material (1.08\% of total organic carbon) composed only of fulvic acids. This indicates marine organic matter.

\section{Study of Kerogen (Table 5, Figure 9)}

Six samples were analyzed for kerogen content. The elemental composition of the kerogen fraction (Table 5) is interpreted using the $\mathrm{H} / \mathrm{C}$ and $\mathrm{O} / \mathrm{C}$ atomic ratios on a Van Krevelen diagram (Figure 9) in order to define the types of organic matter (Tissot et al., 1974). Pyrite represents a large proportion of the ashes $(41 \%)$ in the
Upper Cretaceous Section 368-59-1. The black shale of Core 18, Section 2, which has the highest content of organic carbon, is located between path I and path II but close to the beginning of path II. All the other samples from Site 367 are located close to the beginning of path II, except Core 23, Section 2, which is in an intermediate position between types II and III. This sample corresponds to "shale and clay" material. All the samples show a very low evolution stage on the diagram.

Samples from Site 368 are also close to path II, but they are farther from the beginning of path II than the other samples. That location indicates a somewhat more advanced stage of evolution, and the older Core 63 , Section 3 is even farther from path II.

All the black shale can be compared with aliphatic and alicyclic-rich kerogens of type II which are commonly found in organic matter from marine origin deposited in a reducing environment. The Lower Cretaceous sample of Section 367-23-2 is attributed to a mixture of continental and marine organic matter. All

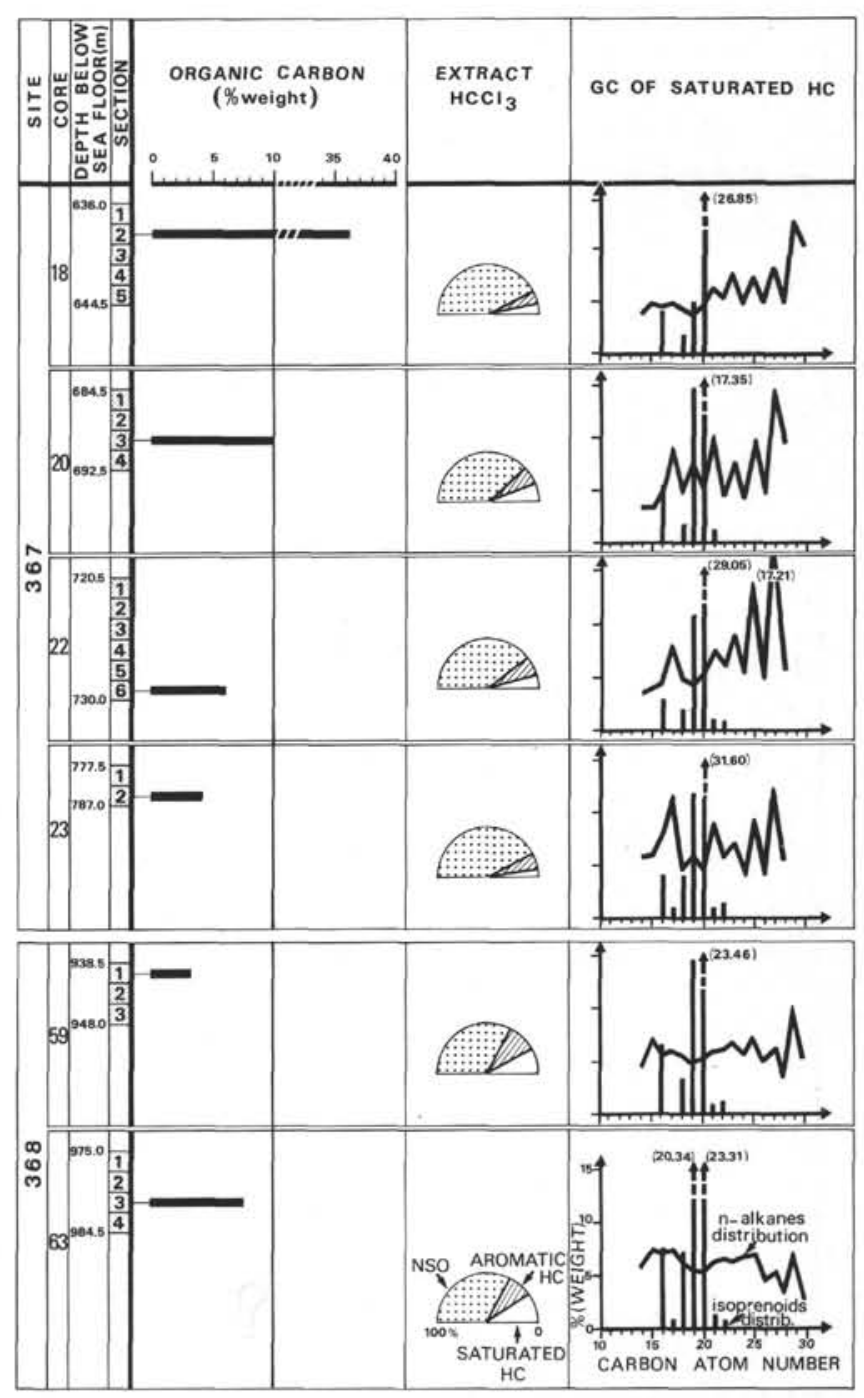

Figure 6. Organic carbon content; gross composition of chloroformic extracts; distribution of normal alkanes and isoprenoids in the C14-C30 range. 
SITE 367
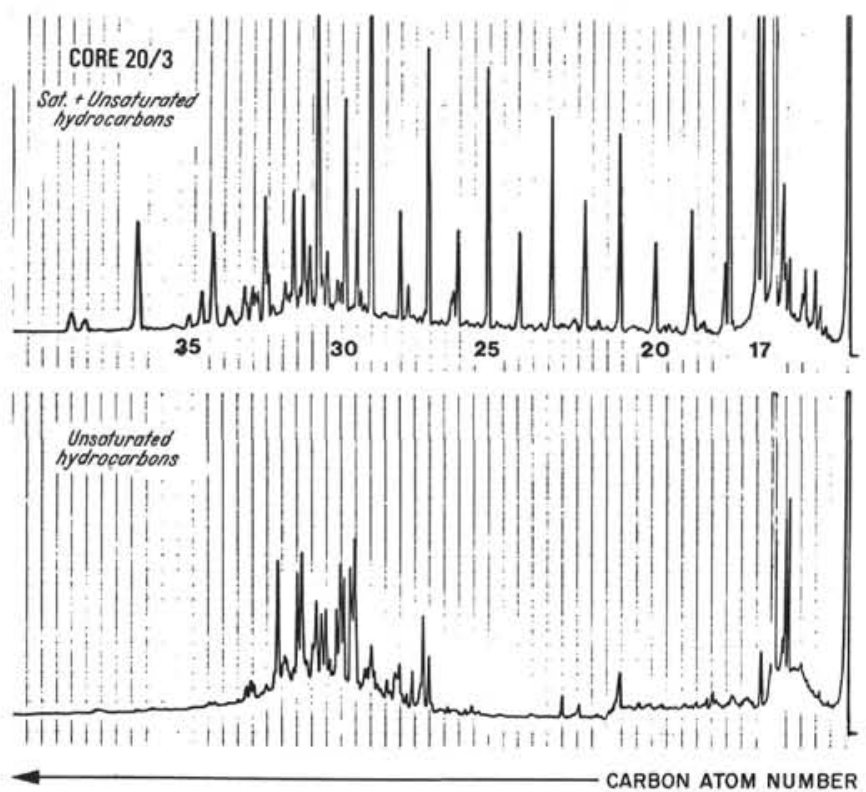

Figure 7a. Extracts. Gas chromatography of saturated (top chromatogram) and unsaturated (bottom chromatogram) hydrocarbons. Site 367, Core 20, Section 3. Black shale, Cenomanian.

\section{SITE 368}
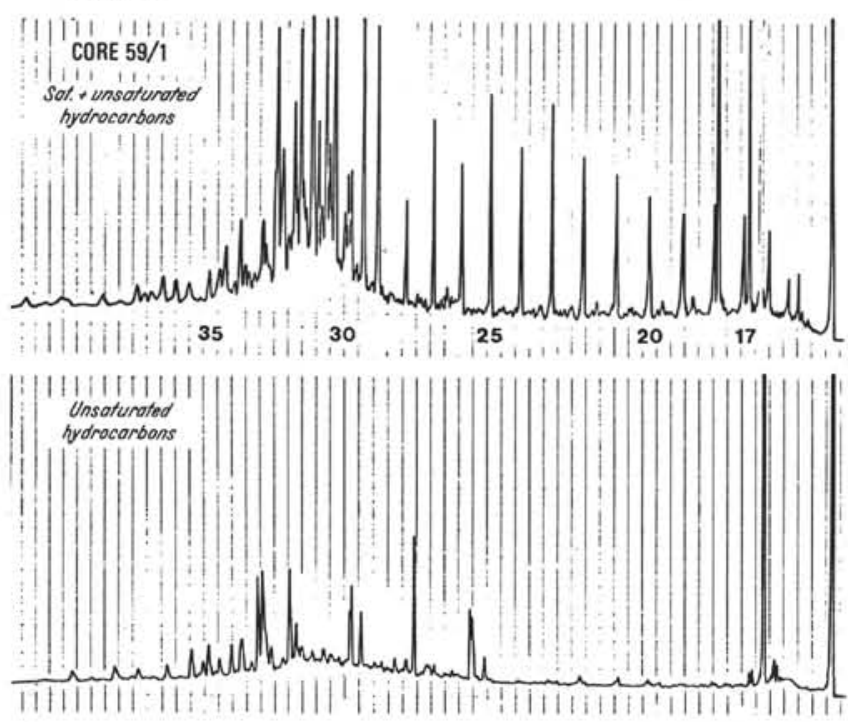

CarBon ATOM NUMBer

Figure 7b. Extracts. Gas chromatography of saturated (top chromatogram) and unsaturated (bottom chromatogram) hydrocarbons. Site 368, Core 59, Section 1, Sandy black shale, Upper Cretaceous.

these characteristics were largely comparable with the previous conclusions deduced from the pyrolysis assays.

\section{DISCUSSION AND CONCLUSIONS}

The organic matter of black shale of Cretaceous age from Leg 41 sediments is of marine origin, and the shales correspond to excellent potential oil source rocks. Their low content of humic compounds suggest a
SITE 368



Figure 7c. Extracts. Gas chromatography of saturated (top chromatogram) and unsaturated (bottom chromatogram) hydrocarbons. Site 368, Core 63, Section 3, Black shale, Turonian to Albian.

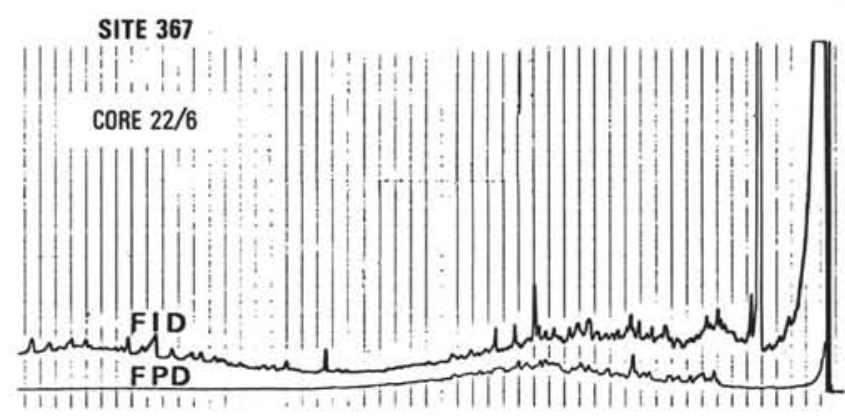

SITE 368
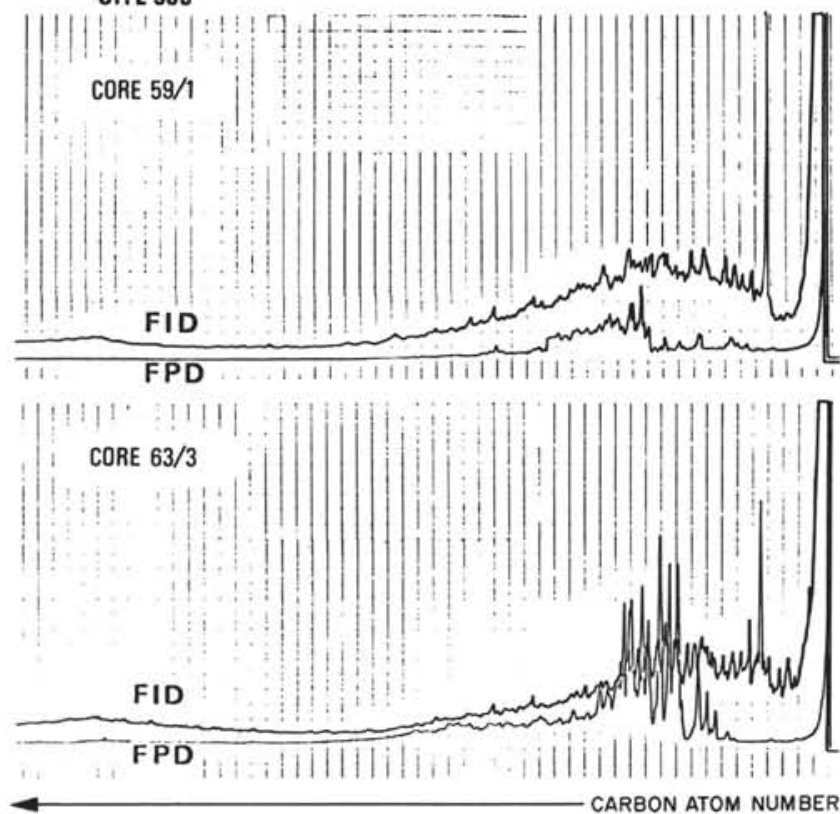

Figure 8. Extracts. Gas chromatography of aromatic fraction (FID) and thiophenic compounds (FPD). 
TABLE 4

Humic Compounds - Carbon Organic Content

\begin{tabular}{|c|c|c|c|c|c|c|}
\hline \multirow[b]{2}{*}{$\begin{array}{c}\text { Sample } \\
\text { (Interval in } \mathrm{cm} \text { ) }\end{array}$} & \multirow[b]{2}{*}{$\begin{array}{l}\text { Depth Below } \\
\text { Sea Floor } \\
(\mathrm{m})\end{array}$} & \multirow{2}{*}{$\begin{array}{l}\text { Total } \\
\text { Organic } \\
\text { Carbon } \\
\text { (wt \%) } \\
\end{array}$} & \multicolumn{3}{|c|}{$\begin{array}{c}\text { Carbon Content } \\
\text { (Percent Total Org. Carbon) }\end{array}$} & \multirow[b]{2}{*}{ FA } \\
\hline & & & $\begin{array}{c}\text { Humic } \\
\text { Compounds } \\
(\mathrm{FA}+\mathrm{HA})\end{array}$ & $\begin{array}{l}\text { Fulvic } \\
\text { Acids } \\
\text { (FA) }\end{array}$ & $\begin{array}{l}\text { Humic } \\
\text { Acids } \\
\text { (HA) }\end{array}$ & \\
\hline \multicolumn{7}{|l|}{ Site 367} \\
\hline $\begin{array}{l}18-2,80-109 \\
20-3,38-38 \\
22-6,0-10 \\
23-2,0-10\end{array}$ & $\begin{array}{l}638.30 \\
687.88 \\
728.00 \\
777.50\end{array}$ & $\begin{array}{r}32.52 \\
9.71 \\
6.13 \\
4.15\end{array}$ & $\begin{array}{r}0.52 \\
10.00 \\
11.58 \\
14.22\end{array}$ & $\begin{array}{l}0.43 \\
1.65 \\
1.63 \\
1.44\end{array}$ & $\begin{array}{r}0.09 \\
8.35 \\
9.95 \\
12.78\end{array}$ & $\begin{array}{c}(4.89) \\
0.20 \\
0.16 \\
0.11\end{array}$ \\
\hline \multicolumn{7}{|l|}{ Site 368} \\
\hline
\end{tabular}

TABLE 5

Kerogens - Elemental Composition and Ash Content

\begin{tabular}{|c|c|c|c|c|c|c|c|c|c|}
\hline \multirow{2}{*}{$\begin{array}{c}\text { Sample } \\
\text { (Interval in } \mathrm{cm} \text { ) }\end{array}$} & \multirow{2}{*}{$\begin{array}{l}\text { Depth Below } \\
\text { Sea Floor } \\
\text { (m) }\end{array}$} & \multicolumn{5}{|c|}{ Weight Percent, on Ash-Free Basis } & \multirow[b]{2}{*}{$\mathrm{H} / \mathrm{C}$} & \multirow{2}{*}{$\begin{array}{r}\mathrm{O} / \mathrm{C} \\
\times 10^{2}\end{array}$} & \multirow{2}{*}{$\begin{array}{l}\text { Ashes } \\
\text { (wt \%) }\end{array}$} \\
\hline & & $\mathrm{C}$ & $\mathrm{H}$ & 0 & $\mathrm{~S}$ & $\mathrm{~N}$ & & & \\
\hline \multicolumn{10}{|l|}{ Site 367} \\
\hline $\begin{array}{l}18-2,80-109 \\
20-3,38-48 \\
22-6,0-10 \\
23-2,0-10\end{array}$ & $\begin{array}{l}638.30 \\
687.88 \\
728.00 \\
777.50\end{array}$ & $\begin{array}{l}67.12 \\
67.81 \\
65.78 \\
69.10\end{array}$ & $\begin{array}{l}7.90 \\
7.02 \\
7.25 \\
6.37\end{array}$ & $\begin{array}{l}11.33 \\
14.97 \\
13.75 \\
16.80\end{array}$ & $\begin{array}{r}11.44 \\
7.36 \\
10.85 \\
4.60\end{array}$ & $\begin{array}{l}2.21 \\
2.84 \\
2.37 \\
3.13\end{array}$ & $\begin{array}{l}1.41 \\
1.24 \\
1.32 \\
1.11\end{array}$ & $\begin{array}{l}12.66 \\
16.55 \\
15.67 \\
18.24\end{array}$ & $\begin{array}{r}7.94 \\
17.00 \\
19.88 \\
31.22\end{array}$ \\
\hline \multicolumn{10}{|l|}{ Site 368} \\
\hline $\begin{array}{l}59-1,97-107 \\
63-3,17-27\end{array}$ & $\begin{array}{l}939.49 \\
978.17\end{array}$ & $\begin{array}{l}77.61 \\
78.47\end{array}$ & $\begin{array}{l}7.53 \\
7.65\end{array}$ & $\begin{array}{l}9.61 \\
5.75\end{array}$ & $\begin{array}{l}2.79 \\
5.27\end{array}$ & $\begin{array}{l}2.47 \\
2.86\end{array}$ & $\begin{array}{l}1.16 \\
1.17\end{array}$ & $\begin{array}{l}9.28 \\
6.49\end{array}$ & $\begin{array}{l}43.04 \\
22.46\end{array}$ \\
\hline
\end{tabular}

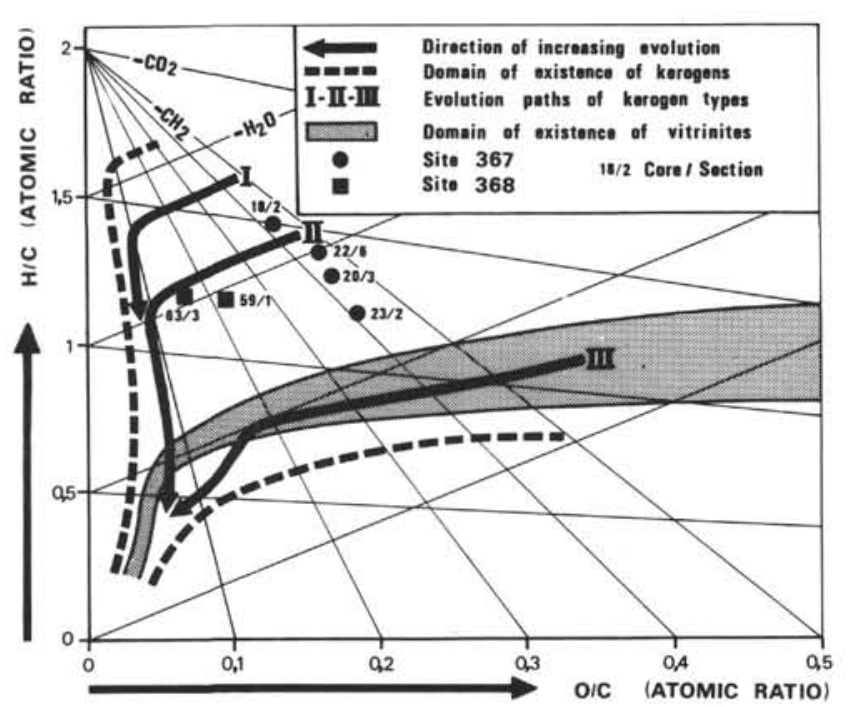

Figure 9. Kerogens. $\mathrm{H} / \mathrm{C}$ and $\mathrm{O} / \mathrm{C}$ diagram.

low original content of continental organic matter as confirmed with pyrolysis assays. However, some continental input is present in the Lower Cretaceous shale of Section 367-23-2. The relatively low stage of evolution of sediments from Site 367 is shown from pyrolysis indices, chloroformic extracts, and kerogen data. A somewhat higher evolution is apparent for the samples from Site 368, especially for the oldest sample, from beneath a volcanic sill. This latter sample corresponds to the beginning of the principal zone of oil formation.

\section{REFERENCES}

Castex, H., Roucache, J., and Boulet, R., 1974. Le soufre thiophénique dans les pétroles et les extraits de roche. Analyse par spectrométrie de masse et chromatographie en phase gazeuse: Rev. Inst. Franc. Pétrole, v. 24, p. 3-40.

Durand, B. and Espitalie, J., 1973. Etude de la matière organique au cours de l'enfouissement des sédiments: C.R. Acad. Sci., Paris, D-276, p. 2253-2256.

Durand, B., Espitalie, J., Niccuse, G., and Combaz, A., 1972. Etude de la matière organique insoluble (kérogène) des argiles du Toarcien du Bassin de Paris. Première partie-Etude par les procédés optiques. Analyse élémentaire. Etude en microscopie et diffraction électroniques: Rev. Inst. Franc. Pétrole, v. 27, p. 865-884.

Espitalié, J., Durand, B., Roussel, J.C., and Souron, C., 1973. Etude de la matière organique insoluble (kérogène) des argiles du Toarcien du Bassin de Paris. II-Etudes en spectrométrie infrarouge, en analyse thermique différentielle et en analyse thermogravimétrique: Rev. Inst. Franc. Pétrole, v. 28, p. 37-66.

Espitalié, J., Laporte, J.L., Madec, M., Marquis, F., Leplat, P., Paulet, J., and Boutefeu, A., in press. Méthode rapide de caracterisation des roches mères, de leur potentiel pétrolier et de leur degré d'évolution. Rev. Inst. Franc. Petrole, v. 32.

Huc, A.Y., 1973. Contribution à l'étude de l'humus marin et de ses relations avec les kérogènes: Thesis, University of Nancy, France. 


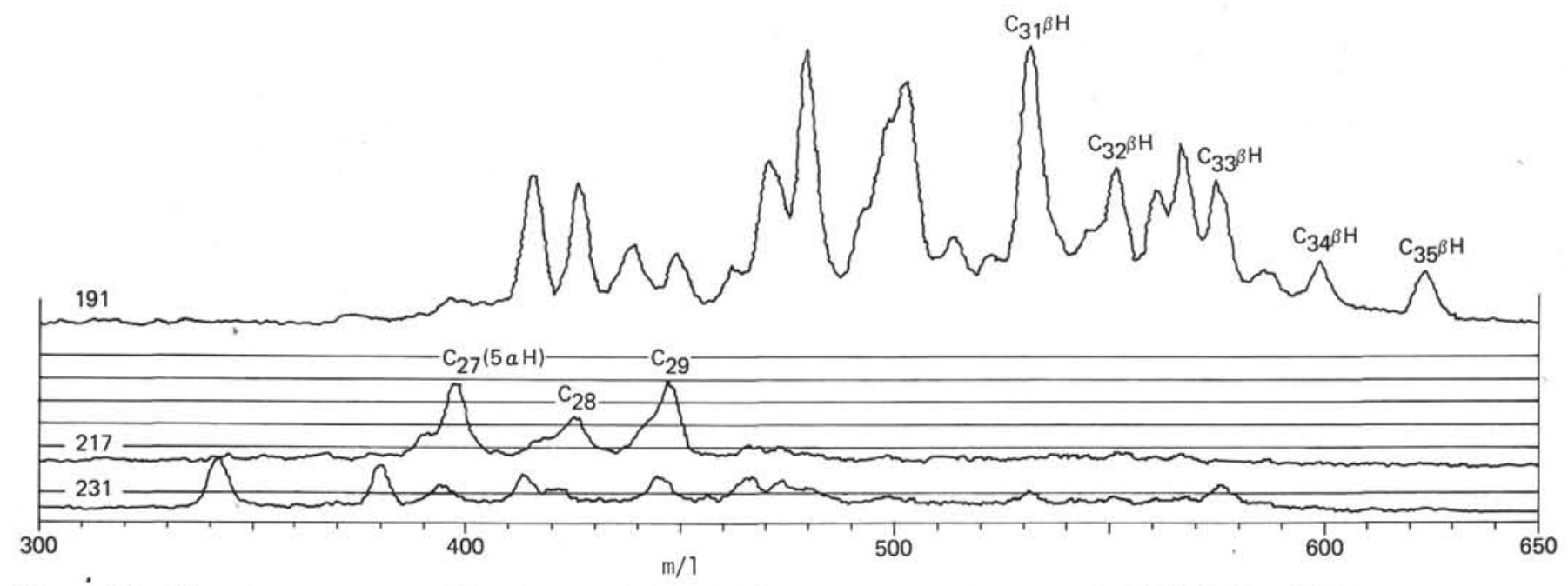

Figure 10. Mass chromatogram of Sample 367-18-2, 80-109 cm, corresponding to peaks 191, 217, and 231.

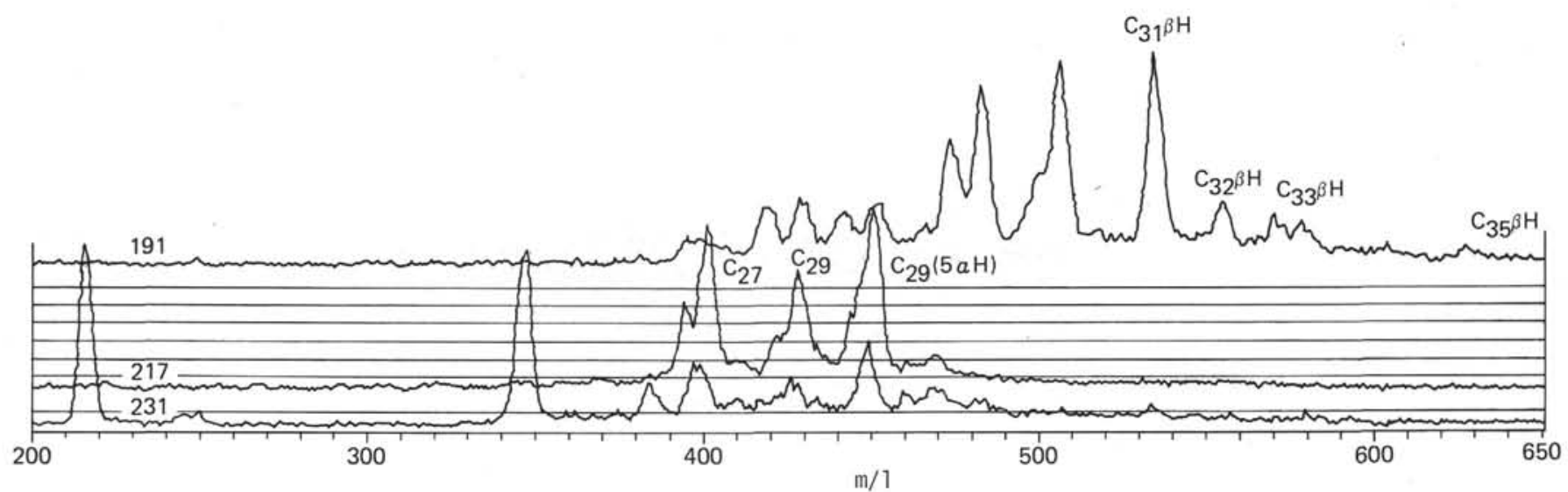

Figure 11. Mass chromatogram of Sample 367-23-2, 6-10 cm corresponding to peaks 191, 217, and 231.

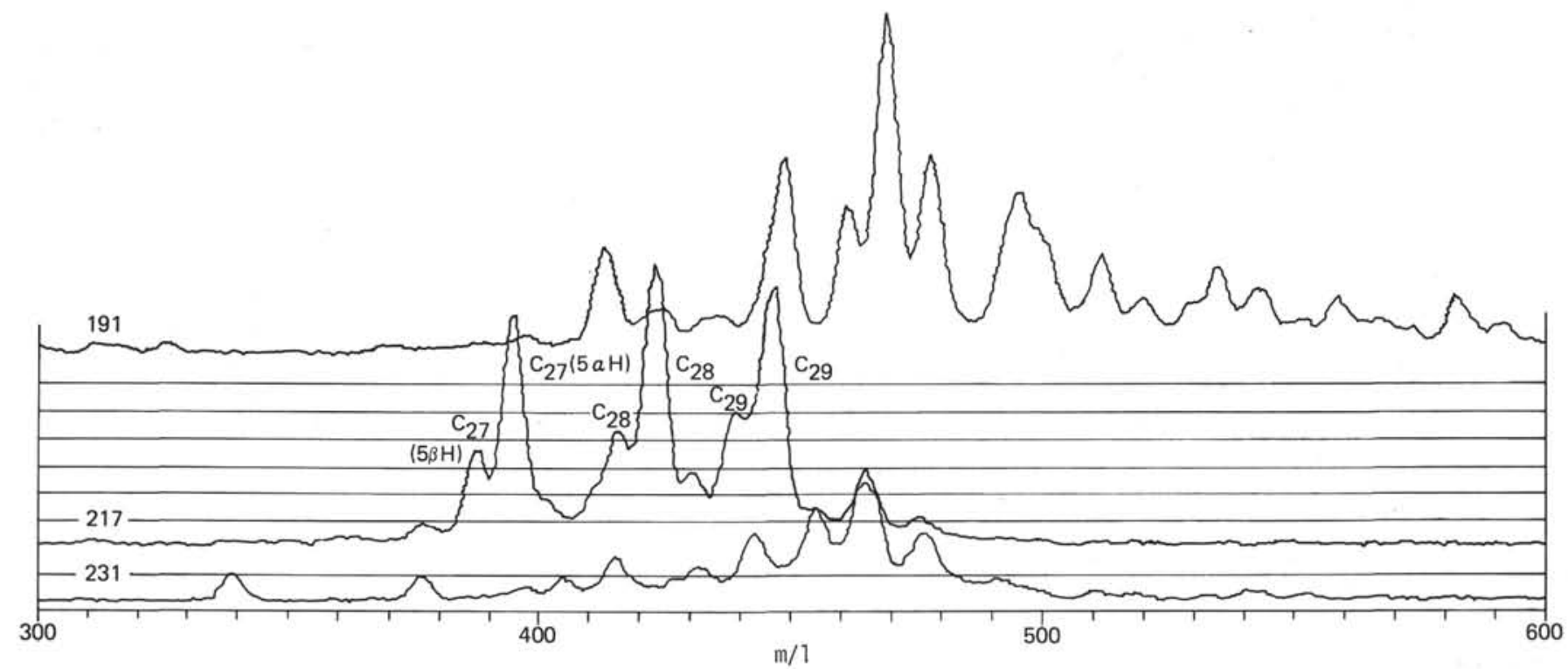

Figure 12. Mass chromatogram of Sample 368-59-1, 97-107 cm, corresponding to peaks 191, 217, and 231. 


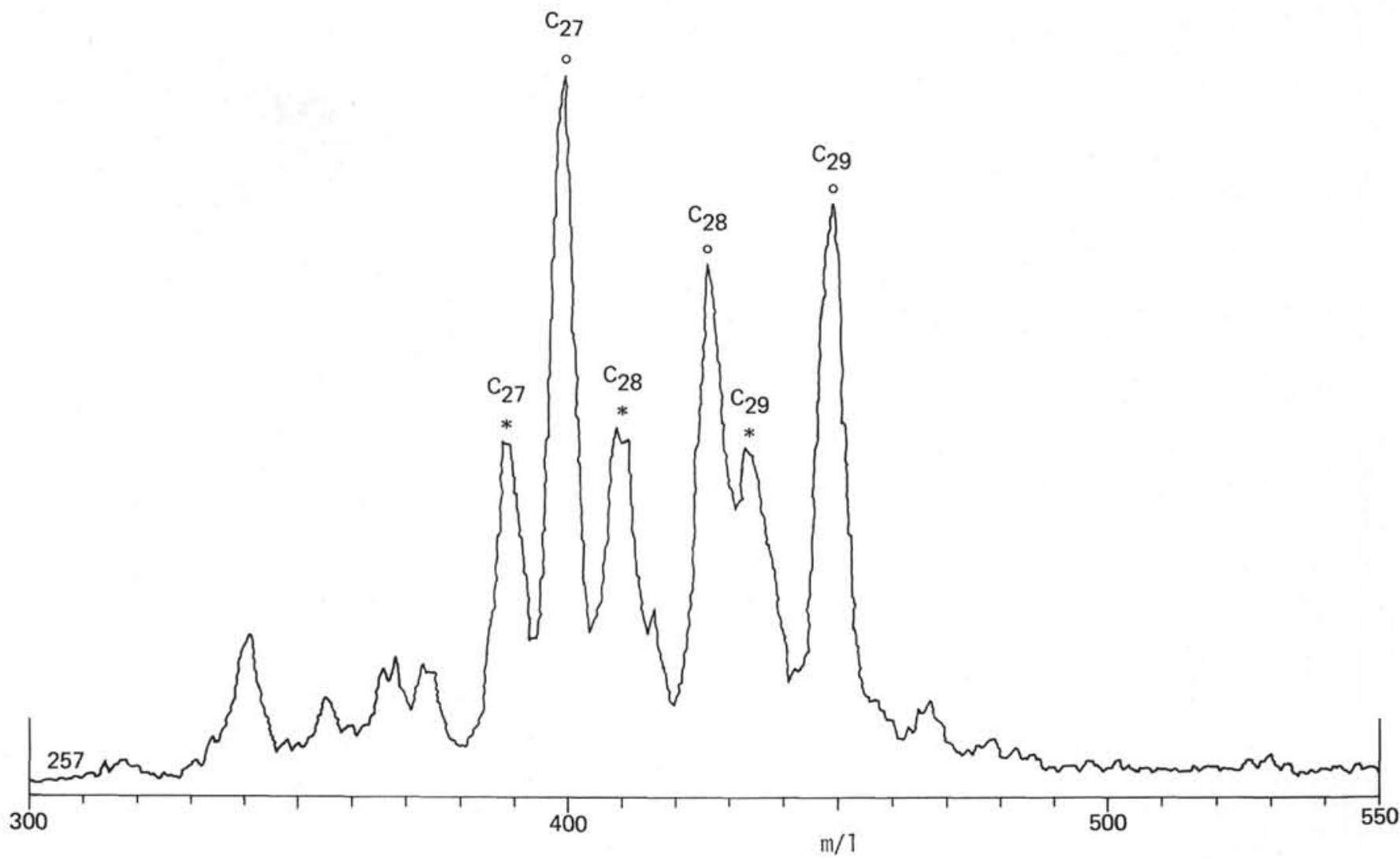

Figure 13. Mass chromatogram of Sample 367-23-2, 10-10 cm, corresponding to peak 257 (sterenes).

Huc, A.Y., Roucache, J., Bernon, M., Caillet, G., and Da Silva, M., 1976. Application de la chromatographie sur couche mince à l'étude quantitative et qualitative des extraits de roche et des huiles. Rev. Inst. Franc. Pétrole, v. 31 , p. 67-98.

Robin, P.L., Rouxhet, P.G., and Durand, B., 1976. Caractérisation des kérogènes et de leur évolution par spectroscopie infra rouge: Advances in organic geochemistry, Madrid.

Tissot, B., Durand, B., Espitalie, J., and Combaz, A., 1974. Influence of the nature and diagenesis of organic matter in the formation of petroleum: Am. Assoc. Petrol. Geol. Bull., v. 58, p. 499-506.

\section{APPENDIX \\ Analysis by Gas Chromatography-Mass Spectrometry of Polycyclic Hydrocarbons}

The hopane, steranes, and methyl steranes have been investigated by computerized GC-MS on Samples 367-18-2, 80-109 cm; 367-23-2,
$0-10 \mathrm{~cm}$; and $368-59-1,97-107 \mathrm{~cm}$. The mass chromatograms corresponding to peaks 191, 217, and 231 are shown on Figures 10, 11 , and 12 . They correspond, respectively, to the hopane, steranes, and methylsteranes series.

Steroids are present in all samples, and are relatively abundant. They occur mostly as steranes in Sections 368-59-1, and mostly as unsaturated sterenes in Sections 367-18-2 and 367-23-2. The sterenes correspond to two different series, which could be the $\Delta^{4}$ and $\Delta^{5}$ sterenes (Figure 13).

Steranes of Section 368-59-1 also correspond to a different series: the 5 a H steranes $\left(\mathrm{C}_{27}, \mathrm{C}_{28}, \mathrm{C}_{29}\right)$ are the major series and the subordinate one is probably the $5 \beta \mathrm{H}$ steranes $\left(\mathrm{C}_{27}, \mathrm{C}_{28}, \mathrm{C}_{29}\right)$. Methylsteranes show a low abundance in all sediments compared to steranes or sterenes.

Triterpanes of the hopane type are particularly abundant in Section $367-18-2$. The naturally occurring and less stable $17(\beta \mathrm{H})$ hopane series is predominant in Sections 367-18-2 and 367-23-2 (up to $C_{35}$, with a single diastereomer in position 22). However, the more stable $17(a \mathrm{H})$ hopane series occurs in subordinate amounts. In Section 36859-1, the $17(a \mathrm{H})$ hopanes are predominant.

The occurrence of unsaturated compounds and of the $17(\beta \mathrm{H})$ hopane series indicates a low stage of diagenesis. However, Section 368-59-1 may correspond to a more advanced stage of diagenesis. 